\title{
Traces of Carnian volcanic activity in the Transdanubian Range, Hungary
}

\author{
István Dunkl ${ }^{1}$ Éva Farics ${ }^{2}$ Sándor Józsa ${ }^{3} \cdot$ Réka Lukács $^{4}$. János Haas ${ }^{5} \cdot$ Tamás Budai $^{2}$
}

Received: 5 December 2017 / Accepted: 5 April 2019 / Published online: 16 April 2019

(c) The Author(s) 2019

\begin{abstract}
The South Alpine-Dinaridic realm was affected by igneous activity in the Middle Triassic; the marine carbonate platforms and the adjacent basins contain highly variable intrusive-volcanic assemblages. We studied the petrography and determined the zircon $\mathrm{U}-\mathrm{Pb}$ ages of the Triassic volcanic products in the Transdanubian Range. The geochemical features and thus the geodynamic context of the magmatism are badly known, as the rocks experienced variable chemical alteration. The exact duration of the igneous activity is also poorly constrained, as the geochronological data of the former studies were obtained mostly by the weathering-sensitive $\mathrm{K}-\mathrm{Ar}$ and $\mathrm{Rb}-\mathrm{Sr}$ methods and thus some data even being younger than the age of the stratigraphic cover. The presence of andesite dikes and of pebbles and cobbles $(<20 \mathrm{~cm})$ of basalt, andesite, rhyolite and of rhyolitic tuff in the Triassic carbonate platform deposits indicates that within the Transdanubian Range formed a volcanic complex in Triassic. The major mineralogical and geochemical features of the Transdanubian igneous suite are similar to the Triassic formations in the Southern Alps. However, dissimilar zircon composition excludes the immediate relationship of the zircon-bearing silicic formations in the two tectonic units. New U-Pb ages show that the beginning of the volcanic activity is probably coeval with the eruption of the widespread "pietra verde" trachytic tuffs in the Upper Anisian-Ladinian successions, but the majority of the ages are younger than those ash layers. The new age constraints give a bench-mark for the termination of the volcanic activity in Carnian time in the Transdanubian Range.
\end{abstract}

Keywords Triassic $\cdot$ Volcanism $\cdot \mathrm{U}-\mathrm{Pb}$ geochronology $\cdot$ Transdanubian Range $\cdot$ Southern Alps

\section{Introduction}

Electronic supplementary material The online version of this article (https://doi.org/10.1007/s00531-019-01714-w) contains supplementary material, which is available to authorized users.

\section{Éva Farics}

eva.gyorfy@gmail.com

1 Department of Sedimentology and Environmental Geology, Geoscience Center, University of Göttingen, Göttingen, Germany

2 Department of Geology and Meteorology, University of Pécs, Pécs, Hungary

3 Department of Petrology and Geochemistry, Eötvös Loránd University, Budapest, Hungary

4 MTA-ELTE Volcanology Research Group, Budapest, Hungary

5 MTA-ELTE Geological, Geophysical and Space Science Research Group, Budapest, Hungary
The Transdanubian Range Unit is a part of the Alcapa Mega-unit (Haas 2013). This fault-bordered terraneincluding the Bakony Mountains and Buda Hills-was located close to the Southern Alps at the northwesternmost edge of the opening Vardar ocean during the Middle-Late Triassic and it belonged to the wide carbonate shelf of the western Tethys (e.g. Kázmér and Kovács 1985; Haas et al. 1995; Vörös 2000). Presence of volcanic tuffs in the Triassic succession of the Transdanubian Range had been recognised already by Böckh (1873) in the Bakony Mountains (Fig. 1). According to Lóczy (1916), the Ladinian "Buchenstein beds" are made up of siliceous limestones, marls and "pietra verde" tuffs. These pyroclastic layers have trachytic composition and they consist of mainly sanidine, biotite, few quartz and secondary minerals (Szabó and Ravasz 1970; Ravasz 1973). Literature data and the present study provide evidence that, in addition to the late Anisian-Ladinian "pietra verde" pyroclastic fall deposits 

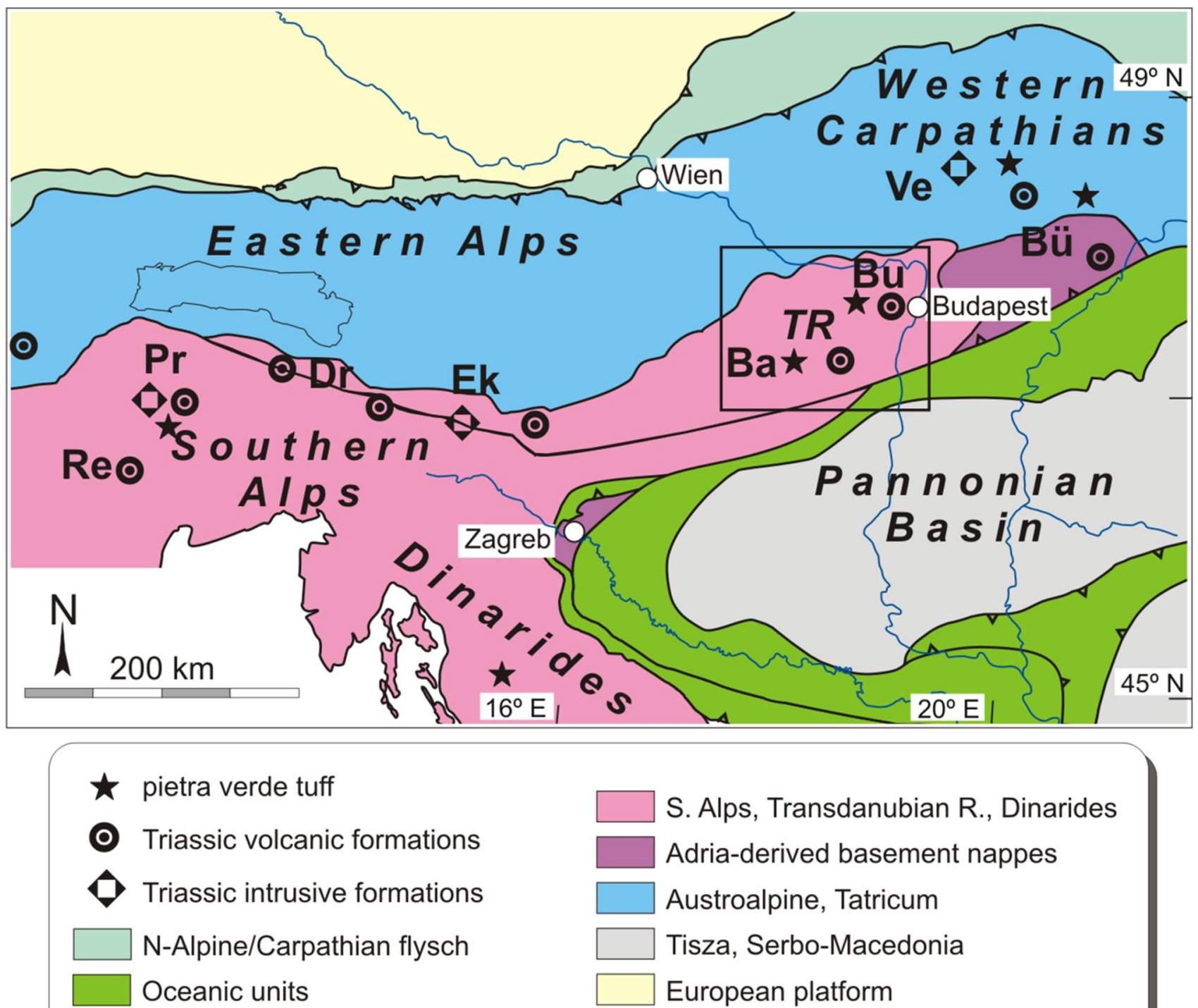

Fig. 1 Simplified structural map of the Southern Alps, the Transdanubian Range (TR) and the surrounding areas with the major occurrences of the Triassic igneous formations (map base after Csontos and Vörös 2004; Schmid et al. 2008). Square represents the geologi-

present in the Southern Alps and derived from an unknown remote volcanic centre, a Middle-Late Triassic volcanism also occurred within or close to the Transdanubian Range. This volcanic activity was documented by Raincsák (1980) and Budai et al. (2001) in the Middle Triassic succession of the Bakony Mountains. A comparison of the Middle Triassic volcanic successions of the Bakony Mountains, Bükk Mountains, Southern Alps and Northern Calcareous Alps was presented by Bechstädt and Mostler (1976), Cros and Szabó (1984), Szoldán (1990) and Harangi et al. (1996). They concluded that the Transdanubian Range may have been relatively close to the South Alpine volcanic cal map of TR (Fig. 2). Abbreviations of the most significant intrusive complexes and tuff/volcanic occurrences: Re Recoaro, $\operatorname{Pr}$ Predazzo, $D r$ Drauzug, Ek Eisenkappel, $B a$ Bakony Mts., $B u$ Buda Hills, Bü Bükk Mts., Ve Vepor Mts.)

centres, whereas the area of the Northern Calcareous Alps was located in a more distal position.

This igneous activity - similarly to those of the Southern Alps-is slightly enigmatic, as it is localized in a passive margin setting during the development of carbonate platform successions. The geodynamic evaluations based on the geochemical character of the Southern Alpine and Dinaridic occurrences yielded ambiguous results, showing signs for both, continental rift and magmatic arc settings (e.g. Bébien et al. 1978; Beltrán-Triviño et al. 2016). Harangi et al. (1996) linked the Middle-Late Triassic volcanism to early extensional events that were followed by a more developed 
rifting phase in the Bükk Mountains, Bakony Mountains and Buda Hills.

The aim of this paper is to complete the information about the puzzle of the dissected parts of the former carbonate platform by new petrographical and geochemical data from the Triassic volcanogenic formations of the Bakony Mountains and Buda Hills and to supply new time constraints by $\mathrm{U}-\mathrm{Pb}$ ages for the duration of the volcanic activity.

\section{Geological setting and traces of Triassic volcanism in the Transdanubian Range}

The Transdanubian Range is the uppermost unit of the Austroalpine Nappe System forming a syncline structure (e.g. Tari et al. 1992). The development of its Upper Permian-Lower Cretaceous formations shows close affinity with that of the Southern Alps (Lóczy 1916; Haas and Budai 1995). The thickest part of the sequence is made up of Triassic shallow marine carbonates (Haas 2013). The Triassic magmatic dikes, volcanic pebbles and cobbles occur in three formations in the Bakony Mountains and in the vicinity of the Buda Hills (Fig. 2).

1. The Upper Anisian Vászoly Formation contains distal, several cm-to-max $2 \mathrm{dm}$-thick, bentonitised trachytic, sometimes graded, primary fallout tuff layers (Budai et al. 1999, 2001, 2015). These strata are equivalent to the slightly thicker "pietra verde" layers in the Dolomites (Mojsisovics 1879), and they are widespread in

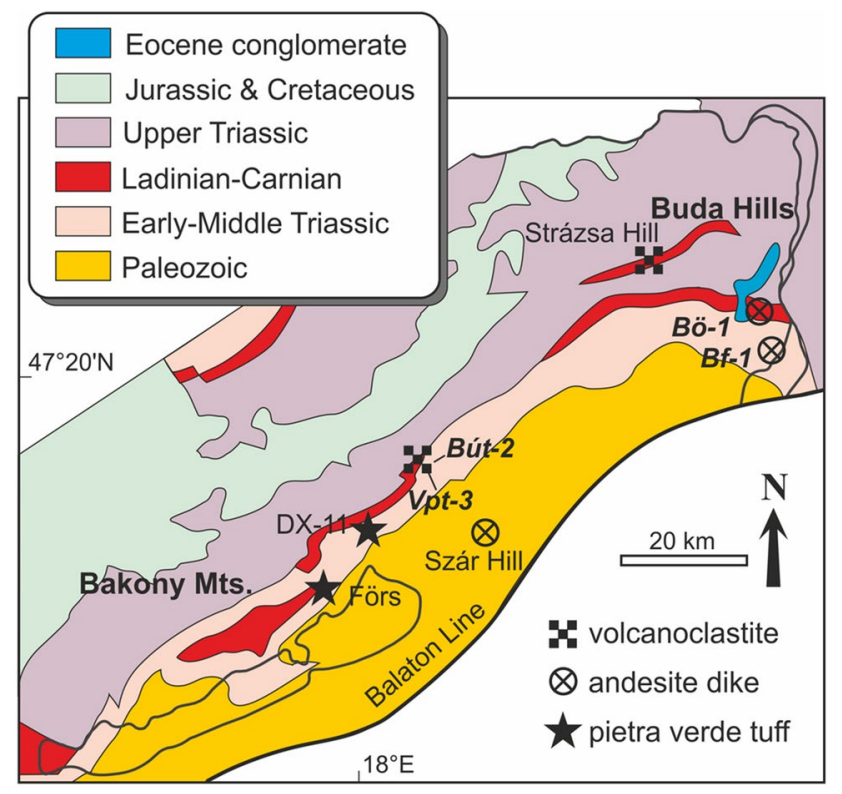

Fig. 2 Simplified geological map of the Transdanubian Range without Cenozoic sedimentary cover (after Haas et al. 2010). Codes of boreholes are in italics (for explanation of abbreviations see Table 1) the entire Southern Alpine-Dinaridic realm (e.g. Obenholzner 1991; Jelaska et al. 2003). The biostratigraphic assignment of these ash layers is well constrained by ammonoid, conodont and radiolarian data to be in the Reitzi Zone (Vörös 1993; Dosztály 1993; Kovács 1994; Pálfy et al. 2003). The zircon content of the ash and bentonite layers of mostly trachytic chemical character allowed highly precise $\mathrm{U}-\mathrm{Pb}$ geochronology (see details below). According to the accurate biostratigraphic, isotope geochronologic and paleomagnetic constraints (Márton et al. 1997) the Felsőörs section was even proposed as a candidate for a Global Stratotype Section and Point for the base of the Ladinian stage (Vörös et al. 1996, 2003).

2. Andesite dikes are known in the quarry of Szár Hill at Polgárdi and they have been detected by the Budaörs-1 and Budafok-1 cored deep drillings of the Buda Hills (Kubovics 1985; Dunkl et al. 2003; Haas et al. 2017). The well exposed, gray porphyritic dikes in the Szár Hill quarry, are 5-10 m thick, while the apparent thicknesses of the partly fault-bounded dikes in the boreholes are between 60 and $186 \mathrm{~m}$ (Budaörs-1 and Budafok-1, respectively).

3. Pebbles of volcanic rocks were recognized in the Middle Triassic sequence of the Bakony Mountains (Raincsák 1980). This volcanoclastic sandstone (Inota Fm.) was correlated with the Wengen Group of the Southern Alps (Mojsisovics 1879; Budai and Vörös 1993; Budai et al. 2001). Clasts of volcanic rocks were also found at the base of the Upper Eocene transgressive sequences of the Buda Hills (Wein 1977; Horváth and Tari 1987; Farics et al. 2015). As will be discussed below, the "pietra verde" tuff originated from remote sources, while the (2) and (3) type formations are local volcanic products within the Transdanubian Range (Budai et al. 2001).

With the exception of a single U-Pb age (Haas et al. 2017), only whole-rock, biotite and hornblende $\mathrm{K}-\mathrm{Ar}$ data are available from the dikes and pebbles (Balogh et al. 1983; Horváth and Tari 1987). The dated aliquots contain highly variable amounts of potassium and radiogenic argon, and they yielded a wide age range from 240 to $25 \mathrm{Ma}$. The isotopic systems have been strongly influenced either by the interaction of the dikes with the carbonate host rocks or by the weathering of the pebbles. Thus, their significance for the timing of eruptions and on the duration of the volcanic activity is weak. 
Triassic igneous activity in the South Alpine realm and their geochronological constraints

According to the palaeogeographic reconstructions, the Transdanubian Range was located in the neighbourhood of the Southern Alps before the Alpine orogeny (Kázmér and Kovács 1985; Haas et al. 1995; Schmid et al. 2008). Thus, it is necessary to insert a short review of the well exposed and studied Triassic igneous formations of the Southern Alps before the evaluation of our new results from the Transdanubian Range.

The "pietra verde" tuff layers (e.g. Obenholzner 1991) were dated both in the Alps and in the Bakony Mountains by high precision and accuracy and those data were contributed even to the global calibration of the Triassic chronostratigraphic scale (Mundil et al. 1996, 2010; Pálfy et al. 2003; Brack et al. 2005; Furrer et al. 2008; Stockar et al. 2012; Wotzlaw et al. 2018). The ID-TIMS data reveal that these trachytic eruptions took place between 242 and 237 Ma.

The Predazzo Complex is the largest of the Triassic intrusive igneous bodies of the Eastern Southern Alps. The intrusive rocks show wide variation in composition: monzonite is the dominant rock type, but monzodiorite, monzogabbro, gabbro with pyroxenite, granite, quartzsyenite and syenite, also occur (Lucchini et al. 1982; Menegazzo Vitturi et al. 1995; Visonà 1997; Carraro and Visonà 2003; Casetta et al. 2018). The dike rocks are also highly diverse: latibasalt, latiandesite, K-basanite, monzosyenite, aplite and lamprophyre were reported by Gallitelli and Simboli (1971). Some of the carbonate platforms of the Dolomites are covered by subaerial basaltic flows (e.g. Monte Agnello), but submarine formations like pillow lavas and hyaloclastite-rich volcano-sedimentary formations are more common in the intra-platform basin fill (Gaetani et al. 1981; Preto et al. 2001; Bosellini et al. 2003; Budai et al. 2005; Németh and Budai 2009). In the western Southern Alps the Montecampione subvolcanic complex shows slightly more alkaline character, but the sodium, potassium and trace element contents were probably influenced by intense fluid circulation (Armienti et al. 2003).

The geodynamic interpretation of this magmatism is debated because beyond the obvious traces of Triassic synsedimentary extensional tectonics manifested, e.g. by halfgrabens (Bertotti et al. 1993; Budai and Vörös 1993, 2006; Velledits 2006), strike-slip and compressional tectonics make the image more complex (Castellarin and Rossi 1981; Blendinger 1984; Castellarin et al. 1988). However, the wide spectrum of rock types and their trace elements and Hf-isotope systematics would fit to an extensional regime. Beltrán-Triviño et al. (2016) related the Triassic magmatism to an asymmetrical continental rifting process that affected the entire Southern Alps and the adjacent areas. The geodynamic evaluation of the Triassic volcanism in the Dinarides resulted in similar dilemma; the compositional spectrum of the lithologies (from basalt to rhyolite) and their geochemical features match neither to the rifting nor to the arc settings (Bébien et al. 1978).

Evaluating the age constraints from the Predazzo Complex and from other Triassic volcanic formations, we should distinguish between weathering/alteration-sensitive and more robust geochronometers. The $\mathrm{Rb}-\mathrm{Sr}$ and $\mathrm{K}-\mathrm{Ar}$ ages scatter between 230 and 204 Ma (Borsi and Ferrara 1967; Borsi et al. 1968; Ferrara and Innocenti 1974; Webb 1982; Crisci et al. 1984; Laurenzi 1994; Visonà 1997; Balogh and Németh 2005). Similar to the Bakony Mountains, some of these ages clearly post-date the stratigraphically proven age range of the volcanic activity. $\mathrm{U}-\mathrm{Pb}$ and $\mathrm{Sm}-\mathrm{Nd}$ ages (246-224 Ma) are available only from a few igneous bodies of the Southern Alps (Zanetti et al. 2013; Storck et al. 2018), Eisenkappel pluton (Lippolt and Pidgeon 1974; Miller et al. 2011), Western Carpathians (Putiš et al. 2000), Bükk Mountains (Haas et al. 2011; Kövér et al. 2018), Eastern Alps, and northwestern Dinarides (Neubauer et al. 2014).

\section{Samples}

We collected "pietra verde" tuff, volcanogenic sandstone and conglomerate drilling core and outcrop samples from Triassic strata and from the base of the Eocene transgressive sequence that unconformly covers the partly eroded Triassic successions. Actually, all known and accessible volcanic formations (Vászoly Fm., Inota Fm.) were sampled in the Bakony Mountains and Buda Hills. Additionally, we have taken seven pilot samples for geochronology and zircon geochemistry from the Triassic igneous formations of the eastern Southern Alps. The localities of the dated samples are listed in Table 1, and a list of petrographically analysed samples is given in the Electronic Supplementary Material (ESM_1.xls). To represent properly the sources of the coarse volcanic fragments, we performed pebble-population dating (PPD-method; Dunkl et al. 2009) on selected and amalgamated andesite, and acid volcanite + ignimbrite pebbles. These "PPD" samples were composed of a representative selection of 16-54 equal-sized volcanic rock pebbles or pebble fragments.

\section{Analytical methods}

For the petrographic investigation of the volcanic rocks Olympus BH2 polarization microscope was used. The composition of feldspar, pyroxene, and amphibole was 
Table 1 Locality and petrography of the samples yielded usable geochronological results

\begin{tabular}{|c|c|c|c|c|c|c|c|}
\hline Type & Code & Long. $\left({ }^{\circ}\right)$ & Lat. $\left(^{\circ}\right)$ & Elevation $(\mathrm{m})^{\mathrm{a}}$ & $\begin{array}{l}\text { Locality/borehole, depth } \\
\text { (m) }\end{array}$ & Area & Petrography \\
\hline \multirow[t]{2}{*}{ Andesite dikes } & $\mathrm{BU}$ & 18.974 & 47.471 & -577.4 & Budaörs-1, $790.4 \mathrm{~m}$ & Buda Hills & Andesite dike \\
\hline & $\mathrm{Bf}-1$ & 19.021 & 47.409 & -1047 & Budafok-1, $1147 \mathrm{~m}$ & Buda Hills & Andesite dike \\
\hline \multirow[t]{6}{*}{ Volcanogenic sandstones } & $\mathrm{ZS}$ & 18.702 & 47.542 & 222 & Strázsa Hill quarry & Zsámbék basin & Volcanoclastite layer \\
\hline & GYE-5 & 18.183 & 47.208 & 134 & Várpalota-3, 37 m & S. Bakony Mts. & Volcanoclastite layer \\
\hline & GYE-6 & 18.196 & 47.225 & 164 & Bakonykút-2, $21 \mathrm{~m}$ & S. Bakony Mts. & Volcanoclastite layer \\
\hline & GYE-7 & 18.196 & 47.225 & 123 & Bakonykút-2, 62 m & S. Bakony Mts. & Volcanoclastite layer \\
\hline & GYE-3 & 18.950 & 47.463 & 155 & Budaörs, Kálvária Hill & Buda Hills & Volcanogenic sandstone \\
\hline & BU-14 & 18.952 & 47.462 & 150 & Budaörs, Kálvária Hill & Buda Hills & Volcanogenic sandstone \\
\hline \multirow{7}{*}{$\begin{array}{l}\text { Pebble-population sam- } \\
\text { ples from the base of } \\
\text { the Eocene transgres- } \\
\text { sive sequence }\end{array}$} & Bö_blk & 18.955 & 47.464 & 193 & Budaörs, Kő Hill & Buda Hills & Black andesite PPD-1 \\
\hline & A_blk & 18.955 & 47.464 & 193 & Budaörs, Kő Hill & Buda Hills & Black andesite PPD-2 \\
\hline & Bö_gr & 18.955 & 47.464 & 193 & Budaörs, Kő Hill & Buda Hills & $\begin{array}{l}\text { Green acid volcanic } \\
\text { PPD-1 }\end{array}$ \\
\hline & AP_gr & 18.955 & 47.464 & 193 & Budaörs, Kő Hill & Buda Hills & $\begin{array}{l}\text { Green acid volcanic } \\
\text { PPD-2 }\end{array}$ \\
\hline & Bö_ri & 18.955 & 47.464 & 193 & Budaörs, Kő Hill & Buda Hills & Rhyolite tuff PPD \\
\hline & BU-10 & 18.931 & 47.523 & 332 & Budakeszi sanatorium & Buda Hills & Andesite PPD \\
\hline & GYE-4 & 19.036 & 47.590 & 225 & Róka Hill & Buda Hills & Andesite PPD \\
\hline \multirow[t]{2}{*}{ Pietra verde } & Förs & 17.943 & 47.018 & 230 & Felsőörs & S. Bakony Mts. & Bentonitic trachite tuff \\
\hline & DX-11 & 18.020 & 47.134 & 195 & Hajmáskér & S. Bakony Mts. & Bentonitic trachite tuff \\
\hline \multirow{6}{*}{$\begin{array}{l}\text { Triassic igneous samples } \\
\text { from the eastern South- } \\
\text { ern Alps }\end{array}$} & DO-531 & 11.589 & 46.314 & 1310 & Predazzo W & Dolomites & Monzonite \\
\hline & DO-504 & 11.603 & 46.307 & 1052 & Predazzo-Bellamonte & Dolomites & Mela-diorite \\
\hline & DO-32 & 11.221 & 45.721 & 660 & Recoaro N & S. Alps & Rhyolite \\
\hline & SI-X1a & 13.653 & 46.596 & 1110 & Nötsch im Gailtal & Drauzug & Tuffite \\
\hline & EK-1 & 14.590 & 46.477 & 610 & Eisenkappel & Drauzug & Granite \\
\hline & EK-5 & 14.614 & 46.475 & 733 & Eisenkappel & Drauzug & Granite \\
\hline
\end{tabular}

The entire sample list used for petrographical study is in the Electronic Supplementary Material (ESM_1.xls). PPB indicates pebble population dating according to Dunkl et al. (2009)

${ }^{a}$ At boreholes the true elevation of the sample relatively to sea level is indicated

determined with AMRAY 1830 scanning electron microscope with EDAX PV 9800 ED spectrometer at the Eötvös University, Budapest. Major, trace and rare earth elements of the whole-rock samples were measured at the University of Göttingen by X-ray fluorescence analysis, and by ICP-AES and ICP-MS techniques in ACME Labs (Vancouver).

Zircon crystals were fixed on a double-side adhesive tape stuck on a thick glass plate and embedded in a $25 \mathrm{~mm}$ diameter epoxy mount. The crystal mounts were lapped by 2500 mesh SiC paper and polished by 9-, 3-, and 1-micron diamond suspensions. Cathodoluminescence images were obtained using a JEOL JXA 8900 electron microprobe at the University of Göttingen to study the internal structure of the zircon crystals and to select homogeneous parts for in situ age determination.

The U-Pb dating was performed by laser-ablation singlecollector sector-field inductively coupled plasma mass spectrometry (LA-SF-ICP-MS). The method employed for our analyses has been described in detail by Frei and Gerdes (2009). We used a Thermo Element 2 mass spectrometer coupled to a Resonetics excimer laser with Laurin Technic 155 constant geometry ablation cell. All age data presented here were obtained by single-spot analyses with a laser beam diameter of $33 \mu \mathrm{m}$ and a crater depth of approximately $10 \mu \mathrm{m}$. The laser was fired at a repetition rate of $5 \mathrm{~Hz}$ and at nominal laser energy output of $25 \%$. The data reduction is based on the processing of ca. 50 selected time slices (corresponding ca. $14 \mathrm{~s}$ ) starting ca. $3 \mathrm{~s}$. after the beginning of the signal. If the ablation hit zones or inclusions with highly variable actinide concentrations or isotope ratios, then the integration interval was slightly resized or the analysis was discarded ( $\sim 1 \%$ of the spots). The individual time slices were tested for possible outliers by an iterative Grubbs test (applied at $P=5 \%$ level). The age calculation and quality control are based on standard-sample bracketing using GJ-1 zircon reference material (Jackson et al. 2004). For further control the Plešovice zircon (Sláma et al. 2008), the 91,500 zircon (Wiedenbeck et al. 1995) and the FC-1 zircon (Paces and Miller 1993) were analysed as "secondary standards". The results obtained on the zircon reference 

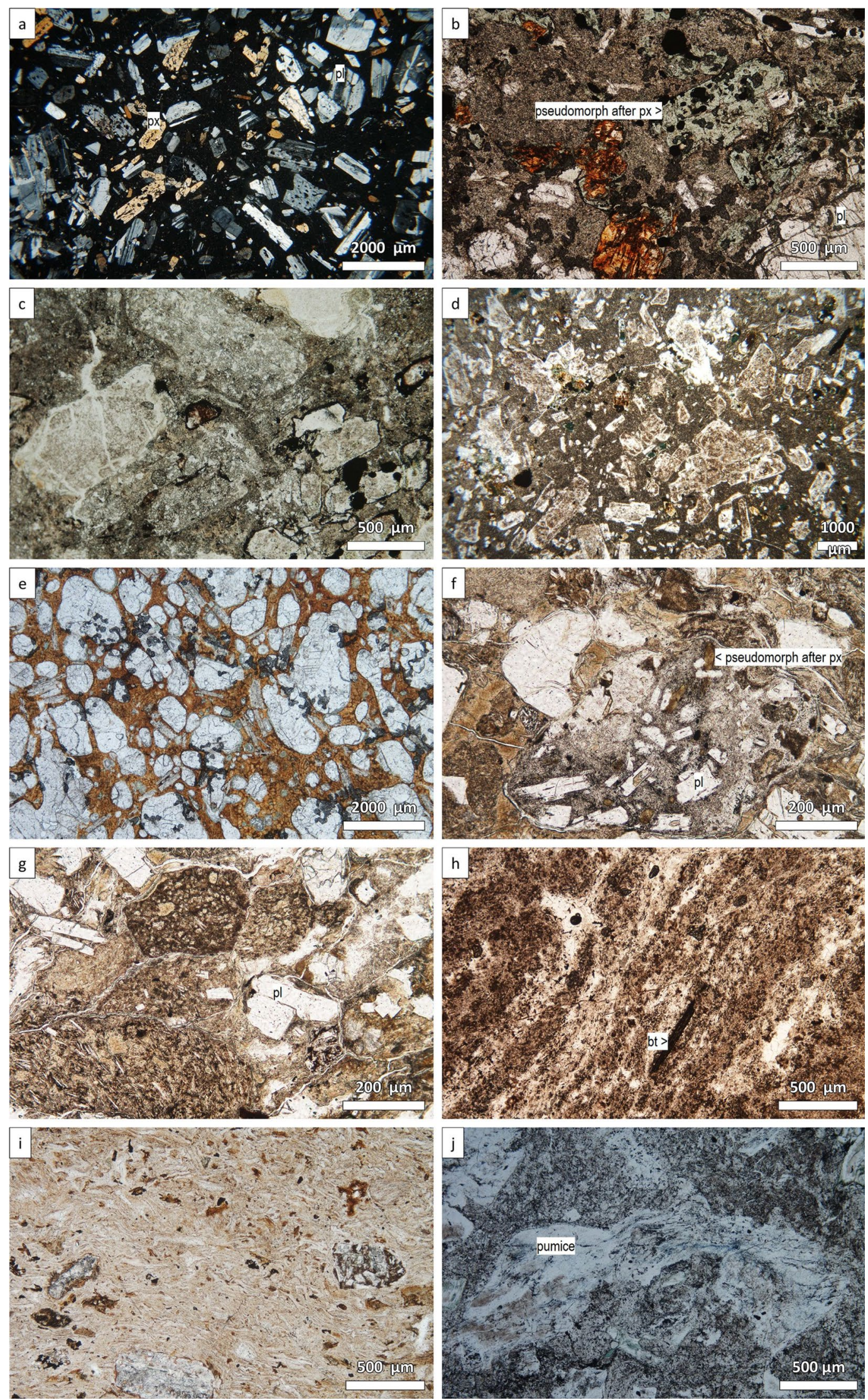
4Fig. 3 Characteristic photomicrographs showing the textures of Middle-Late Triassic volcanic rocks from the Transdanubian Range. $B \ddot{o}-$ 1 Budaörs-1 borehole, Bút-2 Bakonykúti-2 borehole; for the localities see Fig. 2. a Texture of fresh andesite (crossed N), Bö-1, $773 \mathrm{~m}$ (from Farics et al. 2015). b Texture of weakly altered andesite. The pyroxene is altered to secondary minerals, but the plagioclase is fresh (1 N), Bö-1, 775.9 m. c Strongly altered andesite clast in Eocene conglomerate with pseudomorphs of phenocrysts (1 N), Budakeszi. d Texture of K-trachyte-rims of K-feldspar along altered plagioclase (by K-metasomatism) and pseudomorph after pyroxene (1 N), Bö-1, $808.6 \mathrm{~m}$. e Strongly vesiculated texture of a basalt clast in the volcanogenic sandstone/conglomerate $(1 \mathrm{~N})$, Hideg Valley, Inota. $\mathbf{f}$ Texture of andesite clast (1 N), Bút-2, 62 m (from Farics and Józsa 2017). g Texture of basalt/andesite clasts in volcanogenic rock (1 N), Bút-2 $62 \mathrm{~m}$. h Texture of flow banding rhyolite clast (1 N), Hideg Valley. i Texture of moderately welded ignimbrite clast $(1 \mathrm{~N})$, Strázsa Hill. j Texture of acid tuff clast in Eocene conglomerate (1 N), Kő Hill (Farics et al. 2015)

materials express the precision and the accuracy of the dating method applied (see details in Electronic Supplementary Material ESM_2.pdf). Drift- and fractionation-corrections and data reductions were performed by our in-house software (UranOS; Dunkl et al. 2008). The concordia plots were constructed by the help of Isoplot/Ex 3.0 (Ludwig 2012).

\section{Results}

\section{Petrography of the Triassic volcanic products of the Transdanubian Range}

\section{Dike rocks}

The Triassic volcanic formations are often altered, most of the phenocrysts are replaced by secondary minerals and we can observe only pseudomorphs after them. Due to strong alteration, it is often not possible to achieve a reliable geochemical classification. In these cases, we characterized the samples according to their petrographic features.

The lava and dike rocks are mostly comprised of andesite. The unaltered porphyritic andesite contains large-zoned labradorite-andesine and small andesine-basic oligoclase crystals, hypersthenic orthopyroxene, and subordinately augitic clinopyroxene and biotite. The amphibole is hornblende in composition and it was found only in the andesite dikes of the Szár Hill (Fig. 3a). Ilmenite, apatite, garnet, magnetite, zircon and monazite are the accessory minerals. The phenocrysts are often replaced by clay and opaque minerals, chlorite, chalcedony, carbonate, and sericite (Fig. 3b, c). In the fine-grained groundmass thin laths of plagioclase, and variable amounts of partly altered (chloritized) glass are present. In the samples from the lower part of the dike in Budaörs-1 well-intense K-metasomatism was detected, the plagioclase altered to K-feldspar (Fig. 3d). Complete alteration of the groundmass to secondary silica is observed, especially in the volcanic clasts of the Eocene conglomerates. The vesicles are filled mostly by chalcedony and glauconite. The andesite often contains microdiorite inclusions.

\section{Triassic volcanogenic sandstones and conglomerates}

In the Bakony Mountains and in the Strázsa Hill quarry (Zsámbék), the volcanogenic sandstones and conglomerates form clast-supported, polymict deposits. Subangularto-subrounded mafic-intermediate volcanic clasts are usually much larger (up to $20 \mathrm{~cm}$ ) and more common than the subrounded acidic volcanic clasts $(\leq 3 \mathrm{~cm})$. The phenocrysts are completely altered to secondary minerals, but three types of mafic lithologies can be distinguished. One type contains abundant vesicles and a few pseudomorphs after plagioclase, pyroxene and olivine phenocrysts (Fig. 3e). The other type has an intersertal texture with plagioclase microliths in the groundmass and few pseudomorphs after plagioclase and mafic phenocrysts. The third type is microgabbro with intergranular texture; the xenomorphic mafic minerals occur in the spaces among the plagioclase laths. Some of the andesites are characterized by the presence of porphyric labradorite-andesine plagioclase, hypersthenic orthopyroxene and few biotite as well as laths of andesine-basic oligoclase plagioclase in the groundmass (Fig. 3f, g). In several pebbles the plagioclase has been replaced by K-feldspar due to intense K-metasomatism. The latite-trachyte pebbles are characteristically different from the andesite, they contain primary alkali feldspar (K-feldspar) and less plagioclase. Another type of basaltic/andesitic clasts is vesicle-rich and contains only plagioclase phenocrysts (Fig. 3g). The acidic volcanic pebbles consist of quartz, K-feldspar and biotite. Rhyolite contains dark and light flow banding and has poorly developed micropoikilitic texture (Fig. 3h). Three types of devitrificated rhyolite lava and rhyolite tuff can be found. The first one consists of mostly pumice and few glass shards with very few labradorite phenocrysts and more acidic plagioclase microliths. The second one has perlitic texture, and the third one has spherulitic texture. Acidic tuff clasts (only in the Strázsa Hill quarry) contain pumice and Y-shaped glass shards, pseudomorphs after $\mathrm{K}$-feldspar and biotite flakes, as well as lithic fragments (Fig. 3i). Beside the lithoclasts, the labradorite-basic oligoclase, hypersthenic orthopyroxene, hornblende amphibole, biotite, augitic clinopyroxene and altered olivine crystal fragments are in the volcanogenic sandstone layers of the Bakony Mountains, as well as strongly altered plagioclase (mostly altered to K-feldspar), biotite, pyroxene, quartz in the volcanogenic sandstones of the Strázsa Hill quarry. 


\section{Volcanic clasts from the base of Eocene conglomerates}

In the basal layers of the Eocene conglomerate of the Buda Hills we found mostly andesite and acidic lava and tuff pebbles (Fig. 3j).

\section{Geochemistry}

The volcanic rocks showing mafic petrographical characters are strongly altered and are not suitable for geochemical analysis (LOI up to 20\% ; Electronic Supplementary Material ESM_3.xls). However, there are some less altered intermediate and felsic volcanic samples from Buda Hills, Strázsa Hill quarry and Bakony Mountains that yielded useful major and trace element data. Nevertheless, these rocks still have some significant LOI content, therefore their compositions should be evaluated with caution. All samples are plotted on the total alkali versus silica (TAS) diagram after recalculation to anhydrous basis (Fig. 4). They fall mostly into the andesite field, whereas a few samples are rhyolite. The samples showing trachyandesite-trachyte compositions could have experienced some alkali enrichment during alteration, whereas alkali leaching can not be excluded in case of a few samples. Immobile trace elements can be effectively used as indicators for rock types (Pearce 1996) even for altered and slightly metamorphosed rocks. Based on the $\mathrm{Nb} / \mathrm{Y}$ vs. $\mathrm{Zr} /$ $\mathrm{TiO}_{2}$ diagram the analysed rocks are mainly andesite in spite of their TAS classification.

The immobile trace elements suggest subalkaline affinity (Fig. 4), and they plot in the active continental margins field in the tectonomagmatic setting discrimination diagram of Gorton and Schandl (2000) for felsic and intermediate rocks (Fig. 5). The samples having andesitic petrographical character usually show enrichment in LIL elements $(\mathrm{Ba}, \mathrm{Rb}, \mathrm{Th}$, $\mathrm{U})$ and negative anomalies for certain HFS elements (Nb, $\mathrm{P}, \mathrm{Ti})$, although the latter ones are not always pronounced (Fig. 6). The REE patterns of most andesite samples are similar with negative Eu anomaly, suggesting plagioclase fractionation. Notably the samples classified as rhyolite and trachyte based on their petrographic character show much larger compositional distribution, having lower and higher values for LREE. This compositional variation can be traced also on the multivariate trace element diagrams (Fig. 6).

\section{Mineral chemistry}

The strongly altered character of the studied volcanic rocks is reflected in their mineral assemblage, since only a few samples contain detectable mafic minerals, such as pyroxene and amphibole. Pyroxene is present only in a few mafic and intermediate volcanic samples of the Transdanubian Range. The orthopyroxene has a composition from En57 to $53 \mathrm{~mol} \%$, while clinopyroxene is of augitic composition.
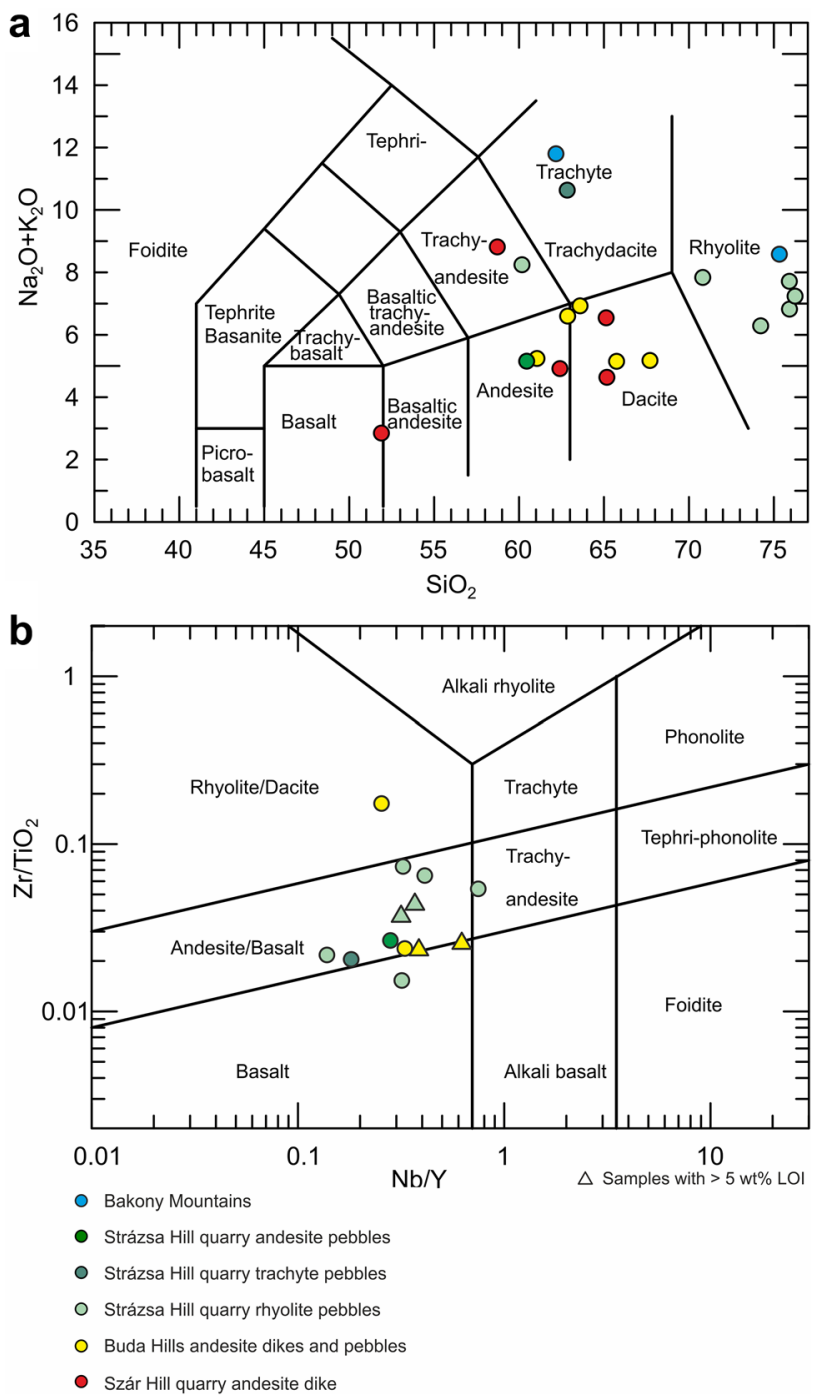

Fig. 4 a Total alkali vs. silica (TAS) classification diagram (Le Bas et al. 1986) and b $\mathrm{Zr} / \mathrm{TiO}_{2}$ vs. $\mathrm{Nb} / \mathrm{Y}$ classification diagram (Pearce 1996) for the Triassic volcanic rocks of Transdanubian Range. Data from Kiss (1954), Harangi et al. (1996), Szabó et al. (1996), Dunkl et al. (2003) and own data. The raw analytical data can be found in the Electronic Supplementary Material (ESM_3.xls)

Amphibole can be found only in the samples from Szár Hill quarry and wells of Bakony Mountains, they are Mg-hornblende and tschermakite. Plagioclase shows a wide compositional range with An content ranging from 10 to $70 \mathrm{~mol} \%$ (ESM_4.xls and ESM_5.pdf).

\section{Zircon $\mathrm{U}-\mathrm{Pb}$ geochronology}

Laser-ablation ICPMS U-Pb geochronology was performed on 485 separated, CL-mapped, zircon crystals in the GÖochron Laboratories of the University of Göttingen. Some samples have poor zircon yield, due to either their mafic character, or due to the small amount of the available 


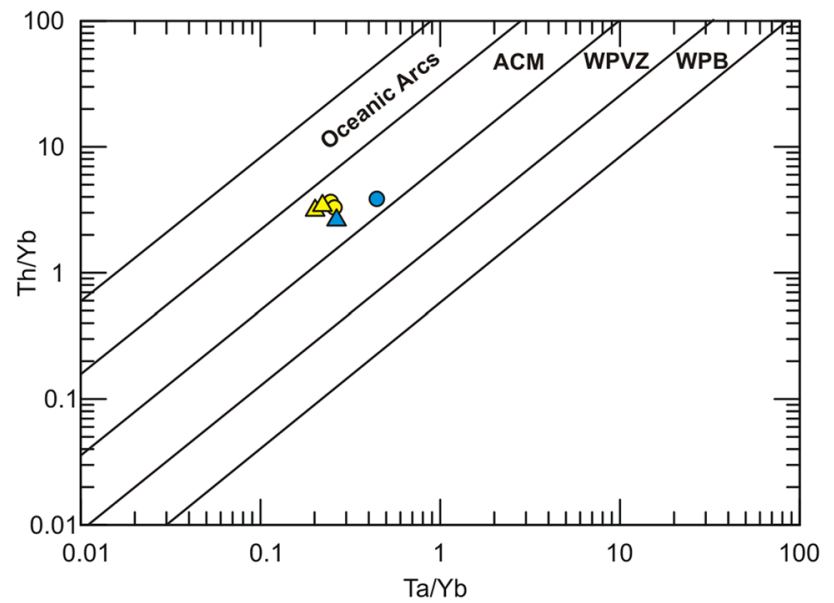

Fig. 5 Implications for the original tectonomagmatic settings of the Triassic volcanic rocks of the Transdanubian Range by the discrimination of Gorton and Schandl (2000). Triangles represent samples with more than $5 \%$ LOI. ACM active continental margins, WPVZ within-plate volcanic zones, $W P B$ within-plate basalts. The legends are the same as in the Fig. 4

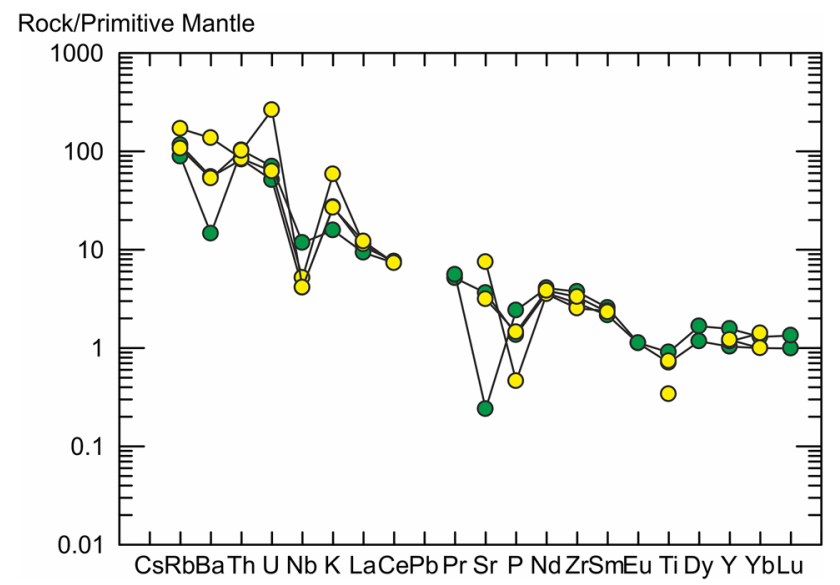

Fig. 6 Multi-element variation diagram for the Triassic volcanic rocks of Transdanubian Range. Normalization values for primitive mantle are from Sun and McDonough (1989). Data from Harangi et al. (1996) and own data. The detailed data are in the Electronic Supplementary Material (ESM_3.xls). The legends are the same as in the Fig. 4

drilling cores. Ca. $20 \%$ of the obtained ages were much older or younger than Triassic; these spots were measured probably on xenocrystals of the Triassic magmatites or on Cenozoic igneous pebbles that were mixed into the PPD samples pooled from the Eocene strata. A synopsis of the results is listed in Table 2, the detailed analytical data are given in the Electronic Supplementary Material (ESM_6.xls and ESM_7.pdf). Where possible, the ages were calculated as concordia age, otherwise we considered only those analyses that are $100 \pm 10 \%$ concordant and applied the Isoplot "ZircAge" algorithm to express a mean age for the crystallization of the most reliable zircon population according to Ludwig (2012). The age data are grouped according to major types of the samples and the mean values with the uncertainty intervals are plotted in Fig. 7.

Before the presentation of the results from Transdanubian Range we should consider the U-Pb data obtained on the Eisenkappel intrusion. This narrow granitoid body is situated along the Periadriatic Line and was dated already by several methods and yielded $227 \pm 7$ Ma biotite and $244 \pm 8 \mathrm{Ma}$ hornblende $\mathrm{K}-\mathrm{Ar}$ ages, $230 \pm 5$ Ma titanite $\mathrm{U}-\mathrm{Pb}$ age and $238.4 \pm 1.9 \mathrm{Ma}$ and $242.1 \pm 2.1 \mathrm{Ma}$ garnet-whole rock Sm-Nd ages (Lippolt and Pidgeon 1974; Miller et al. 2011). Our new laser-ablation zircon $\mathrm{U}-\mathrm{Pb}$ ages $(234.1 \pm 2.5$ and $231.2+5.8-2.2 \mathrm{Ma})$ are close to the formerly measured titanite $\mathrm{U}-\mathrm{Pb}$ ages and obviously younger than the $\mathrm{Sm}-\mathrm{Nd}$ data.

Component analysis was performed on the $\pm 10 \%$ concordant single-crystal ${ }^{206} \mathrm{~Pb} /{ }^{238} \mathrm{U}$ ages determined in the volcanoclastic formations. The individual samples contain relatively low number of single-crystal ages, thus their component analyses do not result in a reliable image on the substantive age components of the entire volcanic activity. That is why we evaluated the pooled data composed from the single-crystal ages of all samples from the Transdanubian Range by the component analysis methods. This pooled data set does not contain the ages obtained on the distal "pietra verde" ash layers, as the aim of the dating and component analysis were to characterize the local volcanic sources. Two different algorithms were used to identify the age components: "PopShare" (Dunkl and Székely 2002) and "DensityPlotter" (Vermeesch 2012). The former procedure assumes Gaussian distribution of the age components and uses the simplex algorithm (Cserepes 1989), while the "Density Plotter" uses the normal mixture modelling algorithm of Galbraith (2005). Beyond the Triassic age components Paleogene and Permian age components were also isolated from the Eocene conglomerates, but these are not in the scope of the current study. The Triassic age spectra could be decomposed to two major age components (Fig. 8). The two procedures resulted in identical mean values: $238.1 \pm 4.0$ (s.d.) and $238.2 \pm 0.9$ (s.e.) for the older, and $228.1 \pm 3.4$ (s.d.) and $229.4 \pm 1.1$ (s.e.) for the younger age component ("PopShare" and "DensityPlotter", respectively). The isolated older age component corresponds to the younger TIMS ages of the "pietra verde" ash layers (e.g. Pálfy et al. 2003; Mundil et al. 2010; Wotzlaw et al. 2018) and indicates that coarse-grained younger volcaniclastic sediments contain reworked fragments also from this slightly older volcanic 
1460

International Journal of Earth Sciences (2019) 108:1451-1466

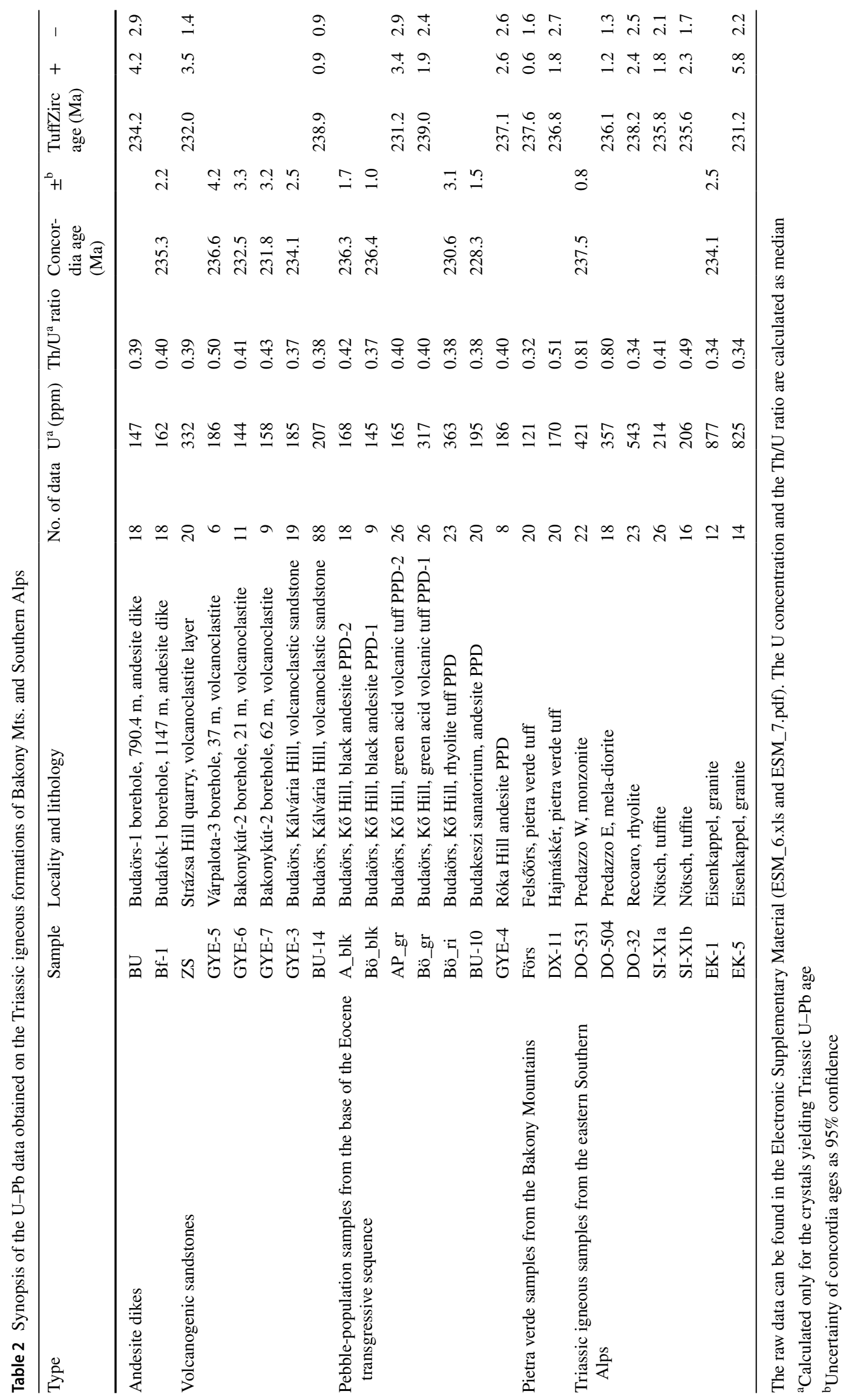

Springer 
Fig. 7 Compilation of the new LA-ICPMS U-Pb ages obtained on the different Triassic volcanic formations of the Transdanubian Range and Southern Alps. PPD: pebble population samples compiled from andesite and rhyolite fragments from the Eocene base conglomerate covering the denudation surface of the Triassic in the Buda Hills. PV (TIMS): Range of 'pietra verde' volcanic activity by high-resolution $\mathrm{U}-\mathrm{Pb}$ dating (see text for sources). Right panel shows the most recent Triassic time scales; (1) Mundil et al. (2010), (2) Cohen et al. (2013, updated)

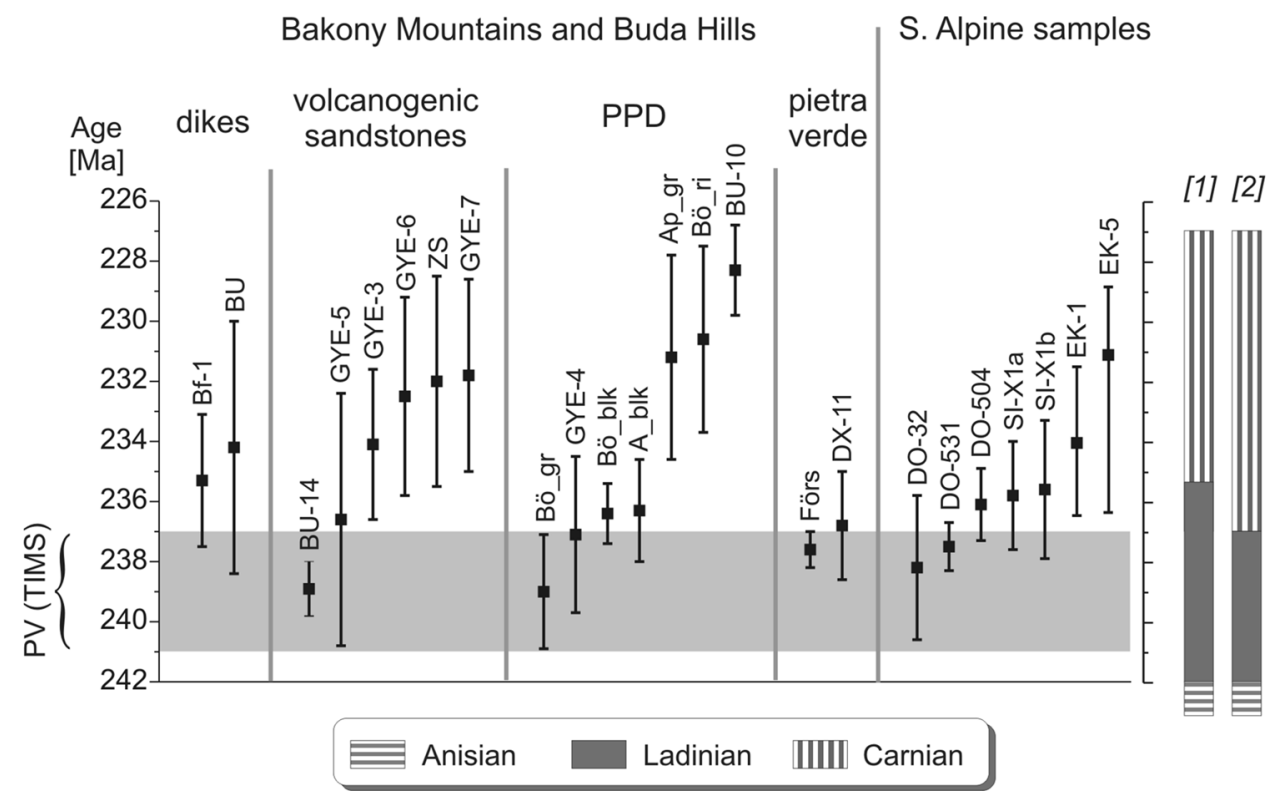

event. The younger age component is an obvious proof on a distinct period of volcanic activity in Carnian time.

\section{Discussion}

The dikes and pebbles are mineralogically and chemically strongly transformed, thus the petrographical character of the volcanic rocks should be deduced mostly from the preserved mineral assemblages. The spectrum is wide, beyond

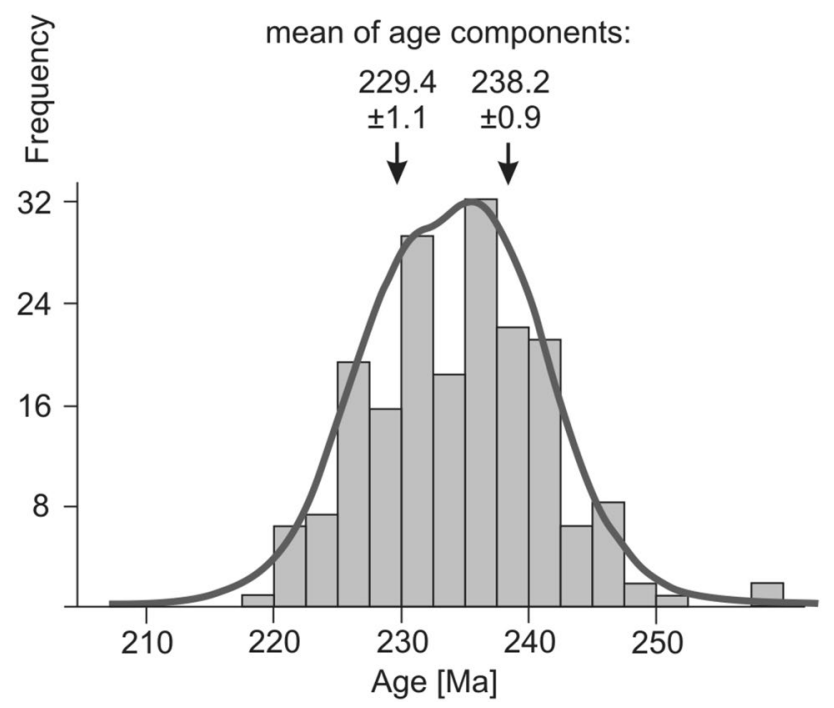

Fig. 8 Compilation of all Triassic zircon U-Pb single-grain ages obtained on the volcanic and volcanoclastic formations of the Bakony Mountains and Buda Hills-without the data measured on the 'pietra verde' tuff layers. $N=274$, the Tertiary ages and the inherited, preTriassic ages are not displayed; bin width $=2.5 \mathrm{Myr}$ quartz and K-feldspar both calcic and sodic plagioclase occur, and the mafic minerals also reflect the highly variable composition: olivine, pyroxene, amphibole and biotite were recognised. Only andesite dikes were hit by the deep drillings and exposed in the quarries, and in the pebbles and cobbles the most dominant lithologies are andesite, basaltic andesite, latite-trachyte, rhyolite and rhyolite tuff. One should consider the selective decomposition; the preserved pebble spectra are biased by the loss of mechanically and chemically more sensitive lithologies like weakly welded tuffs and foid-bearing rocks.

A part of the volcanic rocks has altered chemical composition, as shown by the elevated LOI and the large variation in alkaline contents. In addition, even the relatively immobile HFS trace elements appear to show some secondary modification which makes the rock classification difficult. Nevertheless, most of the analysed samples can be classified as andesites based on fluid-immobile incompatible trace element ratios. The classification of the silicic volcanic rocks is more problematic, since fractionation of accessory minerals strongly affects these element ratios. The revised $\mathrm{Th} / \mathrm{Yb}-\mathrm{Ta} /$ Yb diagram (Gorton and Schandl 2000 after Pearce 1982, 1983 ) is used to infer the tectonic affinity of the volcanic rocks. All of them fall into the active continental margin field based on the relatively low $\mathrm{Ta} / \mathrm{Yb}$ ratios. This geochemical character is similar to the rocks from the Dolomites (Castellarin et al. 1988) and confirm their common petrogenesis. According to our point of view the negative $\mathrm{Nb}-\mathrm{Ta}$ anomaly in the trace element pattern and thus a lower $\mathrm{Ta} / \mathrm{Yb}$ ratio could also originate from lithospheric mantle metasomatized by subduction-related fluids in the past and remobilization during a lithospheric extension event (Sloman 1989 and Bonadiman et al. 1994). Together with the 
presence of the dikes-penetrating platform carbonate and basinal carbonate successions, the abundance and large size of the Triassic volcanic pebbles and cobbles indicate that their source was within the Transdanubian Range. Long transport distance is not a plausible scenario for the provenance of the pebbles. A longer river could not develop on the passive margin that was dominated by the patchy arrangement of carbonate reefs and basins. Longer, wave-driven sediment transport alongshore or between the reef bodies is also not a feasible scenario due to the coarse size and partly angular shape of the detritus and the sensitivity of the volcanic lithologies to weathering. Pebbles of intrusive rocks are present only in minor amount in the Triassic and in the Eocene conglomerates, thus we assume a volcanic centre, but the intrusive-subvolcanic root is less developed than in the case of the Predazzo Complex, or the erosion has not exhumed the subvolcanic level yet.

The new U-Pb ages indicate that in the Transdanubian Range the deposition of the Anisian-Ladinian "pietra verde" tuff was followed by Carnian volcanism with variable, mafic to acid character. Remarkable, that the Triassic volcaniclastic successions in the central and eastern Southern Alps (Garzanti 1985) do not contain a distinct Carnian age group. The youngest U-Pb data of Beltrán-Triviño et al. (2013) form just a diffuse tail of "pietra verde" age components. Our $\mathrm{U}-\mathrm{Pb}$ ages from the Eisenkappel granite confirm its Carnian emplacement age. As these ages are missing from the siliciclastic formations studied by Beltrán-Triviño et al. (2013) we can assume that this pluton was not yet exhumed to the surface and eroded in the Triassic or its contribution in the sediment was strongly diluted due to its minor size.

Outside of eastern Southern Alps Carnian U-Pb ages or age components around 235-220 Ma were reported in the western Southern Alps (Crisci et al. 1984; Cassinis et al. 2008; Zanetti et al. 2013), in the Dinarides (Neubauer et al. 2014), in the Bükk Mountains (Haas et al. 2011; Kövér et al. 2018) and in Asia Minor in clastic sediments and also in a rhyolitic-andesitic volcanic succession (e.g. Ustaömer et al. 2016; Özdamar et al. 2013).

It is useful to consider the actinide content of the dated zircons as a kind of diagnostic "proxy" for provenance purposes. The $\mathrm{U}$ content and the $\mathrm{Th} / \mathrm{U}$ ratio of the dated zircon crystals indicate an obvious difference between the Triassic volcanic rocks of the Transdanubian Range and the pilot samples from the Southern Alps (Fig. 9). Thus, the immediate derivation of the volcanic pebbles found in the Transdanubian Range the silicic formations of Predazzo and Eisenkappel is rather unlikely. $\nabla$ Buda Hills, rhyolite PPD sample

- Buda Hills \& Bakony Mts., other samples

$\diamond$ Recoaro, rhyolite

$\bigcirc$ Predazzo, monzonite \& diorite

Southern

Eisenkappel, granite

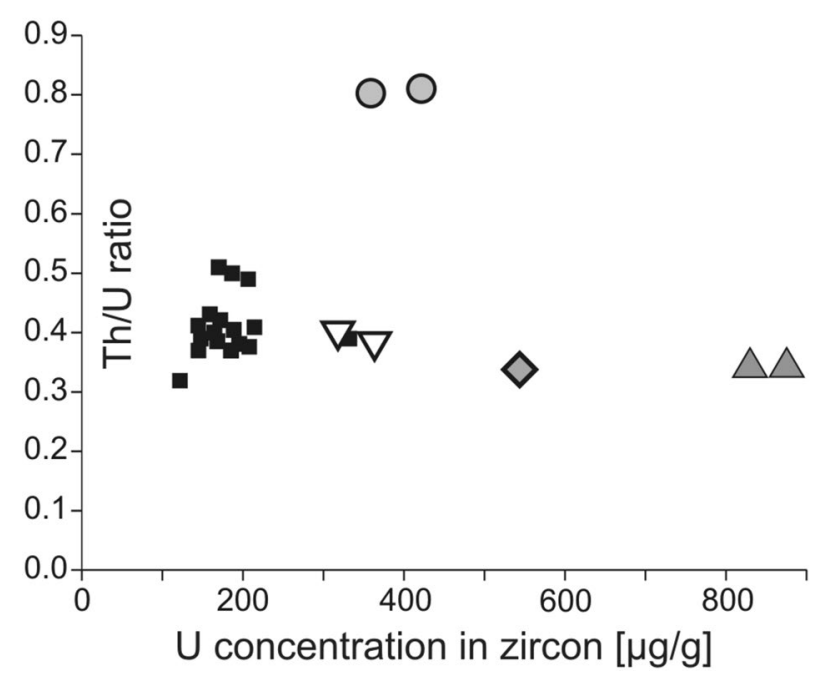

Fig. 9 Actinide composition of the dated zircon samples: median of uranium concentration vs. median of $\mathrm{Th} / \mathrm{U}$ ratio measured in single crystals. Zircons from the Triassic volcanic formations from the Bakony Mountains and Buda Hills form a tight cluster, and it is obvious that the samples from the Southern Alps with acid-intermediate composition have different actinide element concentrations

\section{Conclusions}

- The presence of dikes and the proximal volcaniclastic material indicates volcanic eruptions in the Transdanubian Range in the Middle-Late Triassic.

- The composition of volcanic products covers a wide range from basalt to rhyolite. Although andesites are common, it is possible that the character of volcanism is bimodal, but the selective weathering/alteration biases the initial lithological variation. Volcanic textures are dominating, the intrusive and subvolcanic lithologies are scarce among the pebbles.

- The character of the igneous activity in the Transdanubian Range is similar to the South Alpine one. The local half-graben basins developed coevally with the volcanism indicating that the trigger of the magmatism was the extensional tectonics affecting the passive margin of the Adria plate; however, their geochemistry also shows active margin character.

- Zircon U-Pb ages were determined on andesite dikes, tuff layers and on variable volcanic fragments from different clastic sediments. The sample-mean ages are between 
239 and $228 \mathrm{Ma}$. We could identify two age components by the evaluation of the pooled single-grain ages determined on detrital zircons and on pebble-population samples. Thus the volcaniclastic formations record two major periods of activity of zircon-bearing volcanism at $238 \mathrm{Ma}$ and around 229-228 Ma, indicating well the presence Carnian magmatic activity within the Transdanubian Range.

- The geochemical character of the dated zircons differs from the composition of the zircon pilot samples from the Dolomites and Carnic Alps, and that rules out the origin of the pebbles and cobbles from the sensu stricto South Alpine igneous formations.

- The new zircon U-Pb age of the Eisenkappel granite approves the formerly published titanite $\mathrm{U}-\mathrm{Pb}$ age and thus the emplacement age can be considered also as Carnian.

Acknowledgements Open access funding provided by University of Pécs (PTE). The CL images of the dated zircons were prepared by the kind help of Andreas Kronz (Göttingen). Guido Meinhold (Keele University) sharpened the English text of the manuscript. Discussions with Franz Neubauer (Salzburg), the suggestions of Vincenzo Picotti, Christoph Breitkreuz, an unknown reviewer and the editorial handling of Wolf-Christian Dullo significantly improved the quality of the manuscript. Many thanks for their kind help. The project has been supported by the European Union, co-financed by the European Social Fund (EFOP-3.6.1.-16-2016-00004) entitled by Comprehensive Development for Implementing Smart Specialization Strategies at the University of Pécs.

Open Access This article is distributed under the terms of the Creative Commons Attribution 4.0 International License (http://creativeco mmons.org/licenses/by/4.0/), which permits unrestricted use, distribution, and reproduction in any medium, provided you give appropriate credit to the original author(s) and the source, provide a link to the Creative Commons license, and indicate if changes were made.

\section{References}

Armienti P, Corazzato C, Groppelli G, Natoli E, Pasquarè G (2003) Geological and petrographical study of Montecampione Triassic subvolcanic bodies (Southern Alps, Italy): preliminary geodynamic results. Bollettino della Società geologica italiana 2:67-78

Balogh K, Németh K (2005) Evidence for the Neogene small-volume intracontinental volcanism in western Hungary; K/Ar geochronology of the Tihany Maar volcanic complex. Geol Carpath 56:91-99

Balogh K, Árva-Sós E, Buda GY (1983) Chronology of granitoid and metamorphic rocks of Transdanubia (Hungary). Anuarul Institutului de Geologie şi Geofizică 61:359-364

Bébien J, Blanchet R, Cadet J-P, Charvet J, Chorowicz J, Lapierre H, Rampnoux J-P (1978) Middle Triassic volcanism in the Dinarides of Yugoslavia: its place in the peri-Mediterranean geotectonic evolution (Le volcanisme triasique des Dinarides en Yougoslavie: SA place dans l'évolution géotectonique péri-méditerranéenne, in French with English abstract). Tectonophysics 47:159-176

Bechstädt T, Mostler H (1976) Middle-Triassic reef-basin-development in the western part of the Northern Limestone Alps (RiffBecken-Entwicklung in der Mitteltrias der westlichen Nördlichen Kalkalpen, in German with English abstract). Zdt Geol Ges 127:271-289

Beltrán-Triviño A, Winkler W, von Quadt A (2013) Tracing Alpine sediment sources through laser ablation $\mathrm{U}-\mathrm{Pb}$ dating and Hfisotopes of detrital zircons. Sedimentology 60:197-224

Beltrán-Triviño A, Winkler W, von Quadt A, Gallhofer D (2016) Triassic magmatism on the transition from Variscan to Alpine cycles: evidence from $\mathrm{U}-\mathrm{Pb}, \mathrm{Hf}$, and geochemistry of detrital minerals. Swiss J Geosci 109:309-328

Bertotti G, Picotti V, Bernoulli D, Castellarin A (1993) From rifting to drifting: tectonic evolution of the South-Alpine upper crust from the Triassic to the Early Cretaceous. Sed Geol 86:53-76

Blendinger W (1984) Late Ladinian strike-slip tectonics of the Marmolada-Costabella area (Dolomites). Jahrbuch Geologische Bundesanstalt B-A Wien 127:307-319

Böckh J (1873) The geological conditions of the southern part of the Bakony I (Die geologischen Verhältnisse des südlichen Theiles des Bakony, I, in German). Mittheilungen aus dem Jahrbuche der königlichen ungarischen geologischen Anstalt 2(2):27-182

Bonadiman C, Coltorti M, Siena F (1994) Petrogenesis and T- $\mathrm{fO}_{2}$ estimates of Mt. Monzoni complex (Central Dolomites, Southern Alps): a Triassic shoshonitic intrusion in a transcurrent geodynamic setting. Eur J Miner 6:943-966

Borsi S, Ferrara G (1967) Age determination of the intrusive rocks of Predazzo with $\mathrm{Rb} / \mathrm{Sr}$ and $\mathrm{K} / \mathrm{Ar}$ methods (Determinazione dell' eta delle rocce intrusive di Predazzo con i metodi del $\mathrm{Rb} /$ $\mathrm{Sr}$ e K/Ar, in Italian with English Abstract). Miner Petrogr Acta 14:171-183

Borsi S, Ferrara G, Paganelli L, Simboli G (1968) Isotopic age measurements of the M. Monzoni intrusive complex. Miner Petrogr Acta 14:171-183

Bosellini A, Gianolla P, Stefani M (2003) Geology of the dolomites. Episodes 26:181-185

Brack P, Rieber H, Nicora A, Mundil R (2005) The Global boundary Stratotype Section and Point (GSSP) of the Ladinian Stage (Middle Triassic) at Bagolino (Southern Alps, Northern Italy) and its implications for the Triassic time scale. Episodes 28:233-244

Budai T, Vörös A (1993) The Middle Triassic events of the Transdanubian Central Range in the frame of the Alpine evolution. Acta Geol Hung 36:3-13

Budai T, Vörös A (2006) Middle Triassic platform and basin evolution of the Southern Bakony mountains (Transdanubian Range, Hungary). Riv Ital Paleontol Stratigr 112:359-371

Budai T, Császár G, Csillag G, Dudko A, Koloszár L, Majoros GY (1999) Geology of the Balaton highland: explanation to the Geological map of the Balaton Highland, 1:50,000. Geological Institute of Hungary, Budapest

Budai T, Csillag G, Vörös A, Lelkes GY (2001) Middle to Late Triassic platform and basin facies of the Eastern Bakony Mts. (Transdanubian Range, Hungary). Bull Hung Geol Soc 131:71-95

Budai T, Németh K, Piros O (2005) Middle Triassic platform carbonates and volcanites in the Latemar area (Dolomites, Italy). Annu Rep Geol Inst Hungary Year 2004:175-188

Budai T, Haas J, Piros O (2015) New stratigraphic data on the Triassic basement of the Zsámbék Basin—tectonic inferences. Bull Hung Geol Soc 145:247-257

Carraro A, Visonà D (2003) Mantle xenoliths in Triassic camptonite dykes of the Predazzo Area (Dolomites, Northern Italy): petrography, mineral chemistry and geothermobarometry. Eur J Miner 15:103-115 
Casetta F, Coltorti M, Marrocchino E (2018) Petrological evolution of the Middle Triassic Predazzo Intrusive Complex, Italian Alps. Int Geol Rev 60:977-997

Cassinis G, Cortesogno L, Gaggero L, Perotti CR, Buzzi L (2008) Permian to Triassic geodynamic and magmatic evolution of the Brescian Prealps (eastern Lombardy, Italy). Boll Soc Geol It 127:501-518

Castellarin A, Rossi RML (1981) The Southern Alps: an aborted Middle Triassic mountain chain? Ecl Geol Helv 74:313-316

Castellarin A, Lucchini IF, Rossi PL, Selli L, Simboli G (1988) The Middle Triassic magmatic-tectonic arc development in the Southern Alps. Tectonophysics 146:79-89

Cohen KM, Finney SC, Gibbard PL, Fan J-X (2013) The ICS international chronostratigraphic chart. Episodes 36:199-204 http://strat igraphy.org/ICSchart/ChronostratChart2017-02.pdf. Accessed Feb 2017

Crisci GM, Ferrara G, Mauzzoli R, Rossi PM (1984) Geochemical and geochronological data on Triassic volcanism of the Southern Alps of Lombardy (Italy): genetic implications. Geol Rundschau 73:279-292

Cros E, Szabó I (1984) Comparison of the Triassic volcanogenic formations in Hungary and in the Alps. Paleogeographic criteria. Acta Geol Hung 27:265-276

Cserepes L (1989) Numerical mathematics-for geophysicist students. Tankönyvkiadó, Budapest (in Hungarian)

Csontos L, Vörös A (2004) Mesozoic plate tectonic reconstruction of the Carpathian region. Paleogeogr Paleoclimatol Paleoecol 210:1-56

Dosztály L (1993) The Anisian/Ladinian and Ladinian/Carnian boundaries in the Balaton Highland based on Radiolarians. Acta Geol Hung 36:59-72

Dunkl I, Horváth I, Józsa S (2003) Andesite dikes and skarn formations of Szár Hill, Polgárdi, Hungary. In: Szakáll S, Fehér B (eds) Minerals of Szár Hill. Herman Ottó Museum, Miskolc, pp 55-86 (in Hungarian)

Dunkl I, Frisch W, Kuhlemann J, Brügel A (2009) Pebble population dating as an additional tool for provenance studies-examples from the Eastern Alps. Geol Soc Lond Spec Publ 324:125-140

Dunkl I, Székely B (2002) Component analysis of detrital FT ageswith visualization of the fitting. Salamanca, International Workshop on Fission Track Analysis, Cádiz, 4-7 June 2002. Geotemas 4:63

Dunkl I, Mikes T, Simon K, von Eynatten H (2008) Brief introduction to the Windows program Pepita: data visualization, and reduction, outlier rejection, calculation of trace element ratios and concentrations from LA-ICP-MS data. In: Sylvester P (ed) Laser ablation ICP-MS in the earth sciences: current practices and outstanding issues, vol 40. Mineralogical Association of Canada, Short Course, Canada, pp 334-340

Farics É, Józsa S (2017) Petrographic investigation of the Triassic volcanogenic formations of the Eastern Bakony and interpretation of their genesis. Földtani Közlöny Bull Hung Geol Soc 147:25-38 (in Hungarian with English abstract)

Farics É, Józsa S, Haas J (2015) Petrographic features of lava rock and tuff clast-bearing sedimentary rocks at the base of the Upper Eocene succession in the Buda Hills. Földtani Közlöny Bull Hung Geol Soc 145:331-350

Ferrara G, Innocenti F (1974) Radiometric age evidence of a Triassic thermal event in the Southern Alps. Geol Rundsch 63:572-581

Frei D, Gerdes A (2009) Precise and accurate in situ U-Pb dating of zircon with high sample throughput by automated LA-SF-ICPMS. Chem Geol 261:261-270

Furrer H, Schaltegger U, Ovtcharova M, Meister P (2008) U-Pb zircon age of volcaniclastic layers in Middle Triassic platform carbonates of the Austroalpine Silvretta nappe (Switzerland). Swiss J Geosci 101:595-603
Gaetani M, Fois E, Jadoul F, Nicora A (1981) Nature and evolution of Middle Triassic carbonate Buildup int he Dolomites (Italy). Mar Geol 44:25-57

Galbraith RF (2005) Statistics for fission track analysis. Chapman and Hall/CRC, Interdisciplinary Statistics Series, London

Gallitelli P, Simboli G (1971) Petrological and geochemical research on the rocks of Predazzo and Monzoni (North Italy). Verhandlungen der Geologischen Bundesanstalt 2:326-343

Garzanti E (1985) The sandstone memory of the evolution of a Triassic volcanic arc in the Southern Alps, Italy. Sedimentology 32:423-433

Gorton MP, Schandl ES (2000) From continents to island arcs: a geochemical index of tectonic setting for arc-related and within-plate felsic to intermediate volcanic rocks. Can Miner 38:1065-1073

Haas J (2013) Geology of Hungary. Springer, Berlin

Haas J, Budai T (1995) Upper Permian-Triassic facies zones in the Transdanubian Range. Rivista Italiana Paleontologia Stratigrafia 101:249-266

Haas J, Kovács S, Krystyn L, Lein R (1995) Significance of Late Permian-Triassic facies zones in terrane reconstructions in the Alpine-North Pannonian domain. Tectonophysics 242:19-40

Haas J, Budai T, Csontos L, Fodor L, Konrád GY (2010) Magyarország pre-kainozoos földtani térképe 1:500,000 (Pre-Cenozoic geological map of Hungary, 1:500,000). Hungarian Geological Survey, Budapest

Haas J, Kovács S, Pelikán P, Sz Kövér, Görög Á, Ozsvárt P, Józsa S, Németh N (2011) Remnants of the accretionary complex of the Neotethys Ocean in Northern Hungary. Földtani Közlöny Bull Hung Geol Soc 141:412-466

Haas J, Budai T, Dunkl I, Farics É, Józsa S, Sz Kövér, Götz AE, Piros O, Szeitz P (2017) The Budaörs-1 well revisited: stratigraphic and tectonic implications. Cent Eur Geol. https://doi. org/10.1556/24.60.2017.008

Harangi SZ, Szabó CS, Józsa S, Szoldán ZS, Árva-Sós E, Balla M, Kubovics I (1996) Mesozoic igneous suites in Hungary: implications for genesis and tectonic setting in the northwestern part of Tethys. Int Geol Rev 38:336-360

Horváth E, Tari G (1987) Middle Triassic volcanism in the Buda Mountains. Annales Universitas Scientiarum Budapestiensis de Rolando Eötvös Nominatae, Sect Geol 27:3-16

Jackson S, Pearson N, Griffin W, Belousova E (2004) The application of laser ablation-inductively coupled plasma-mass spectrometry to in situ U-Pb zircon geochronology. Chem Geol 211:47-69

Jelaska V, Kolar-Jurkovšek T, Jurkovšek B, Grušić I (2003) Triassic beds in the basement of the Adriatic-Dinaric carbonate platform of Mt. Svilaja (Croatia). Geologija 46:225-230

Kázmér M, Kovács S (1985) Permian-Paleogene paleogeography along the eastern part of the Insubric-Periadriatic lineament system: evidence for continental escape of the Bakony-Drauzug unit. Acta Geol Hung 28:71-84

Kiss J (1954) Andesite from Szabadbattyán and its importance concerning the genesis of ores (Szabadbattyáni andezit és ércgenetikai jelentősége). Földtani Közlöny Bull Hung Geol Soc 84:183-189 (in Hungarian with English abstract)

Kovács S (1994) Conodonts of stratigraphical importance from the Anisian/Ladinian boundary interval of the Balaton Highland, Hungary. Riv Ital Paleontol Stratigr 99:473-514

Kövér S, Fodor L, Kovács Z, Klötzli U, Haas J, Zajzon N, Szabó C (2018) Late Triassic acidic volcanic clasts in different Neotethyan sedimentary mélanges: paleogeographic and geodynamic implications. Int J Earth Sci 107:2975-2998

Kubovics I (1985) Mesozoic magmatism of the Transdanubian midmountains. Acta Geol Hung 28:141-164

Laurenzi MA (1994) High resolution Ar/Ar chronology of Predazzo magmatic complex (Southem Alps, Italy). Abstracts of the 
Eighth Conference on Geochronology, US. Geological Survey, circular 1107, pp 8

Leake BE, Wolley AR, Arps CES, Birch WD, Gilbert MC, Grice JD, Hawthorne FC, Kato A, Kisch HJ, Krivovichev VG, Linthout K, Laird J, Mandarino J (1997) Nomenclature of Amphiboles: report of the subcommittee on amphiboles of the international mineralogical association commission on new minerals and mineral names. Miner Mag 61:295-321

Le Bas MJ, Le Maitre RW, Streckeisen A, Zanettin B (1986) A chemical classification of volcanic rocks based on the total alkali-silica diagram. J Petrol 27:745-750

Lippolt HJ, Pidgeon R (1974) Isotopic mineral ages of a diorite from the Eisenkappel intrusion, Austria. Z Naturforsch 29:966-968

Lóczy L (1916) The geology and tectonics of the Balaton Highland (Die geologische Formationen der Balatongegend und ihre regionale Tektonik). In: Resultate der wissenschaftlichen Erforschung des Balatonsees 1, Hölzel, Wien (in German)

Lucchini F, Rossi PL, Simboli G (1982) Triassic magmatism in the Predazzo area (Il magmatismo triassico dell' area di Predazzo, in Italian). In: Castellarin A, Vai GB (eds) Guida alla Geologia del Sudalpino centro-orientale. Società Geologica Italiana, Guide Geologiche Regionali, Roma, pp 221-229

Ludwig KR (2012) User's manual for isoplot 3.75: a geochronological toolkit for microsoft excel. Berkeley Geochronol Center Spec Publ 4:70

Márton E, Budai T, Haas J, Kovács J, Szabó I, Vörös A (1997) Magnetostratigraphy and biostratigraphy of the Anisian-Ladinian boundary section Felsőörs (Balaton Highland, Hungary). Albertiana 20:50-57

Menegazzo Vitturi L, Visonà D, Zantedeschi C (1995) Amphibole composition of Predazzo volcano-plutonic complex (Southern Alps, Italy). Mem Sci Geol 47:87-94

Miller C, Thöni M, Goessler W, Tessadri R (2011) Origin and age of the Eisenkappel gabbro to granite suite (Carinthia, SE Austrian Alps). Lithos 125:434-448

Mojsisovics E (1879) The dolomite reefs of South Tyrol and Veneto: contributions to the develeopment of the Alps (Die Dolomit-Riffe von Südtirol und Venetien: Beiträge zur Bildungsgeschichte der Alpen, in German). Hölder, Wien

Morimoto N (1988) Nomenclature of pyroxenes. Miner Petrol 39:55-76

Mundil R, Brack P, Meier M, Rieber H, Oberli F (1996) High resolution $\mathrm{U}-\mathrm{Pb}$ dating of middle Triassic volcaniclastics: time-scale calibration and verification of tuning parameters for carbonate sedimentation. Earth Planet Sci Lett 141:137-151

Mundil R, Pálfy J, Renne PR, Brack P (2010) The Triassic timescale: new constraints and a review of geochronological data. In: Lucas SG (ed) The Triassic timescale, vol 334. Geological Society, London, pp 41-60

Németh K, Budai T (2009) Diatremes cut through the Triassic carbonate platforms in the Dolomites? Evidences from and around the Latemar, Northern Italy. Episodes 32:74-83

Neubauer F, Xiaoming L, Borojević Šoštarić S, Bianca H, Yunpeng D (2014) U-Pb zircon data of Middle-Upper Triassic magmatism in Southern Alps and NW Dinarides: Implications for the Southeast Mediterranean tectonics. In: Buletini i Shkencave Gjeologjike, Special Issue ,Vol. 1/2014, Proceedings XX Congress of the Carpathian-Balkan Geological Association, Tirana, Albania

Obenholzner JH (1991) Triassic volcanogenic sediments from the Southern Alps (Italy, Austria, Yugoslavia)-a contribution to the "Pietra verde" problem. Sed Geol 74:157-171

Özdamar S, Billor MZ, Sunal G, Esenli F, Roden MF (2013) First U-Pb SHRIMP zircon and ${ }^{40} \mathrm{Ar} /{ }^{39} \mathrm{Ar}$ ages of metarhyolites from the Afyon-Bolkardag Zone, SW Turkey: implications for the rifting and closure of the Neo-Tethys. Gondwana Res 24:377-391
Paces JB, Miller JD (1993) Precise U-Pb ages of Duluth Complex and related mafic intrusions, northeastern Minnesota: geochronological insights into physical, petrogenetic, paleomagnetic and tectonomagmatic processes associated with the $1.1 \mathrm{Ga}$ midcontinent rift system. J Geophys Res 98:13997-14013

Pálfy J, Parrish RR, David K, Vörös A (2003) Middle Triassic integrated $\mathrm{U}-\mathrm{Pb}$ geochronology and ammonoid biochronology from the Balaton Highland. J Geol Soc Lond 160:271-284 (Hungary)

Pearce JA (1982) Trace elements characteristics of lavas from destructive plate boundaries. In: Thorpe RS (ed) Andesites. Wiley, New York, pp 525-548

Pearce JA (1983) Role of the sub-continental lithosphere in magma genesis at active continental margins. In: Hawkesworth CJ, Norry MJ (eds) Continental basalts and mantle xenoliths. Shiva, Nantwich, pp 230-249

Pearce JA (1996) A user's guide to basalt discrimination diagrams. In: Wyman DA (ed) Trace element geochemistry of volcanic rocks: applications for massive sulphide exploration. Geol. Ass. Canada Short Course Notes, v. 12 pp 79-113

Preto N, Hinnov LA, Hardie LA, De Zanche V (2001) Middle Triassic orbital signature recorded in the shallow-marine Latemar carbonate buildup (Dolomites, Italy). Geology 29:1123-1126

Putiš M, Kotov AB, Uher P, Salnikova JB, Korikovsky SP (2000) Triassic age of the Hrončok Pre-Orogenic A-type granite related to continental rifting: a new result of $\mathrm{U}-\mathrm{Pb}$ isotope dating (Western Carpathians). Geol Carpath 51:59-66

Raincsák GY (1980) The structure of the Triassic formations at Várpalota-Iszkaszentgyörgy. Annu Rep Geol Inst Hungary 1978:187-196

Ravasz CS (1973) Mineralogical-petrographical studies on Middle Triassic tuffs of the Transdanubian Central Mountains, Hungary. Acta Mineral Petrogr Szeged 21:123-139

Schmid SM, Bernoulli D, Fügenschuh B, Matenco L, Schefer S, Schuster R, Tischler M, Ustaszewski K (2008) The AlpineCarpathian-Dinaride-orogenic system: correlation and evolution of tectonic units. Swiss J Geosci 101:139-183

Sircombe KN (2004) AgeDisplay: an EXCEL workbook to evaluate and display univariate geochronological data using binned frequency histograms and probability density distributions. Comput Geosci 30:21-31

Sláma J, Košler J, Condon DJ, Crowley JL, Gerdes A, Hanchar JM, Horstwood MSA, Morris GA, Nasdala L, Norberg N, Schaltegger U, Schoene B, Tubrett MN, Whitehouse MJ (2008) Plešovice zircon-a new natural reference material for $\mathrm{U}-\mathrm{Pb}$ and $\mathrm{Hf}$ isotopic microanalysis. Chem Geol 249:1-35

Sloman LE (1989) Triassic shoshonites from the Dolomites, Northern Italy: alkaline rocks in a strike-slip setting. J Geophys Res 94:4655-4666

Stockar R, Baumgartner PO, Condon D (2012) Integrated Ladinian bio-chronostratigraphy and geochronology of Monte San Giorgio (Southern Alps, Switzerland). Swiss J Geosci 105:85-108

Storck JC, Brack P, Wotzlaw JF, Ulmer P (2018) Timing and evolution of Middle Triassic magmatism in the Southern Alps (Northern Italy). J Geol Soc. https://doi.org/10.1144/jgs20 $18-123$

Sun S-s, McDonough WF (1989) Chemical and isotopic systematics of oceanic basalts: implications for mantle composition and processes. Geol Soc London Spec Publ 42(1):313-345

Szabó C et al (1996) Mineralogy and geochemistry of magmatic rocks of Budafok-1 borehole (Budafok-1 (Bf-1) fúrás magmás összletének ásványkőzettani és geokémiai vizsgálata, in Hungarian). Department of Petrology and Geochemistry, Eötvös Loránd University, Hungary, p 27

Szabó I, Ravasz CS (1970) Investigation of the Middle Triassic volcanics of the Transdanubian Central Mountains, Hungary. Ann Hist Natur Mus Nat Hung 62:31-51 
Szoldán ZS (1990) Middle Triassic magmatic sequences from different tectonic settings in the Bükk Mts., NE Hungary. Acta Mineral Petrogr Szeged 31:25-42

Tari G, Horváth E, Rumpler J (1992) Styles of extension in the Pannonian Basin. Tectonophysics 208:203-219

Ustaömer T, Ustaömer PA, Robertson AHF, Gerdes A (2016) Implications of $\mathrm{U}-\mathrm{Pb}$ and $\mathrm{Lu}-\mathrm{Hf}$ isotopic analysis of detrital zircons for the depositional age, provenance and tectonic setting of the Permian-Triassic Palaeotethyan Karakaya Complex, NW Turkey. Int J Earth Sci 105:7-38

Velledits F (2006) Evolution of the Bükk Mountains (NE Hungary) during the Middle-Late Triassic asymmetric rifting of the Vardar-Meliata branch of the Neotethys Ocean. Int J Earth Sci 95:395-412

Vermeesch P (2012) On the visualisation of detrital age distributions. Chem Geol 312-313:190-194

Visonà D (1997) The Predazzo multipulse intrusive body (Western Dolomites, Italy). Field and mineralogical studies. Memorie di Scienze Geologiche 49:117-125

Vörös A (1993) Redefinition of the Reitzi Zone at its type region (Balaton area, Hungary) as the basal zone of the Ladinian. Acta Geol Hung 36:15-38

Vörös A (2000) The Triassic of the Alps and Carpathians and its interregional correlation. In: Hongfu Yin, Dickins JM, Shi GR, Jinnan Tong (eds) Permian-Triassic evolution of Tethys and Western Circum-Pacific. Elsevier, New York, https://doi.org/10.1016/ s0920-5446(00)80011-4
Vörös A, Szabó I, Kovács S, Dosztály L, Budai T (1996) The Felsőörs section: a possible stratotype for the base of the Ladinian stage. Albertiana 17:25-40

Vörös A, Budai T, Haas J, Kovács S, Kozur H, Pálfy J (2003) A proposal for the GSSP at the base of the Reitzi Zone (sensu stricto) at Bed 105 in the Felsöörs section, Balaton Highland, Hungary. Albertiana 28:35-47

Webb JA (1982) A Carnian age from the Mt. Monzoni intrusive complex, western Dolomites, Italy. In: Odin GS (ed) Numerical dating in stratigraphy. Wiley, New York, pp 875-876

Wein GY (1977) Tectonics of Buda Hills. Budapest, Geological Institute of Hungary, $\mathrm{p} 76$

Wiedenbeck M, Allé P, Corfu F, Griffin WL, Meier M, Oberli F, von Quadt A, Roddick JC, Spiegel W (1995) Three natural zircon standards for $\mathrm{U}-\mathrm{Th}-\mathrm{Pb}, \mathrm{Lu}-\mathrm{Hf}$, trace element and REE analyses. Geostand Newslett 19:1-23

Wotzlaw JF, Brack P, Storck JC (2018) High-resolution stratigraphy and zircon $\mathrm{U}-\mathrm{Pb}$ geochronology of the Middle Triassic Buchenstein Formation (Dolomites, northern Italy): precession-forcing of hemipelagic carbonate sedimentation and calibration of the Anisian-Ladinian boundary interval. J Geol Soc 175:71-85

Zanetti A, Mazzucchelli M, Sinigoi S, Giovanardi T, Peressini G, Fanning M (2013) SHRIMP U-Pb zircon Triassic intrusion age of the Finero mafic complex (Ivrea-Verbano Zone, Western Alps) and its geodynamic implications. J Petrol 54:2235-2265 